\title{
SARTRE AND POLITICAL LEGITIMACY
}

(This article appeared previously in Insemational Philosophical Quarterly, Vol. XXXI, no. 2, June 1991, pp. 141-152, and is reprinted with permission.)

Sartre's politics can be characterized as a monumental attempt to think against oneself, that is to say engineer the collectivization of his philosophy of contingency and individual freedom. The result of this transformation is his political "anarchism" (a term used by Sartre himself although without any particular historical reference). ${ }^{1}$ This is perhaps the best way to describe his positions, at once during his mainly apolitical youth before the war, during his relations with the Communist movement in the late forties and in the fifties, and most clearly during his work with the various liberation and youth movements of the late sixties and the seventies. In that sense, T. Flynn, for example, is quite right to see in one of the slogans of the 1968 revolt in France, "l'imagination au pouvoir," a good concentrate of Sartrean politics. ${ }^{2}$ I would further contend that this final period is one of Sartrean anarchism par excellence: during that time he finally finds himself at home in the political movements in France, although in the seventies his writings are far less original than before, no doubt because Sartre had lost the guilty conscience he had in the postwar period both towards the Communists and towards himself which seemed to give rise to his most brilliant work in political issues. I want to reflect for a moment on this anarchism, first by briefly stating its basic structure, then by evoking some of its manifestations, finally by suggesting its significance for us today. I hope thereby to put into some sort of perspective that most elusive object: Sartre's conception of political legitimacy.

\footnotetext{
'See for example "Autoportrail ì soixante-dix ans," in Situations X, Gallimard, Paris, 1976, p. 155.

${ }^{2}$ T. Flynn, "L'imagination au pouvoir: the evolution of Sartre's social and political thought," in Critical Essays on Jean-Paul Sartre, R. Wilcocks (ed.), G. K. Hall and Co., Boston, 1988.
} 
The structuring thesis of Sartre's politics is what can be called his philosophical anarchism, namely the freedom defined in his ontology of nothingness as the non-coincidence of consciousness with itself, and best expressed (even before the definition of the For-itself in Being and Nothingness) as the freedom of the imagination, whereby consciousness holds the real at a distance and makes that everything is possible. ${ }^{3}$ The model here is the creative freedom of the artist; on this basis Sartre attempts to think his own existence (in Nausea as made explicit in Words), existence in general (in Being and Nothingness), and finally the political sphere. One reason Sartre's political thought exerts such fascination, while being widely criticized for its weaknesses and turnabouts, is that it proceeds from his fundamental personal fantasy: self-creation, and that he projects it into the debates of modern political theory which are themselves obsessed with the question of legitimacy. Like Rousseau who feeds his political project with the meat of intimate experience, ${ }^{4}$ it is Sartre as bastard, comedian and traitor, who continues the last two centuries' quest for the founding principles of political order. On the basis of his effort to legitimize existence without recourse to the lies of the "spirit of seriousness, " Sartre tries to come to grips with the political problem of modernity: the self-institution of society without a transcendent framework of legitimacy. Thus while confronting Stalinism, the main political challenge of his generation, Sartre makes his the dramatic image the French Revolution gave of itself-or at least the Jacobins as inspired by Rousseau-, that of starting anew after the destruction of the Old Order: the myth of a new origin symbolized by the execution of the King. ${ }^{5}$ In his autobiography Sartre evokes his uncertain overcoming of the fantasy of the

\footnotetext{
${ }^{3}$ See the basic opposition of imagination and perception put in place in L'Imaginaire, Gallimard, Paris, 1939 (Psychology of the Imagination, Philosophical Library, N.Y., 1948), particularly in the last chapter on ant.

4Although seidom explored, Sartre's theoretical relationship with Rousseau seems to me one of the most fruitful approaches for the understanding of Sartrean thought. I tried to suggest some avenues for this in my "Solitude et sociabilite: Rousseau et Sartre," in Dialogue, Canadian Philosophical Review, vol. 24, No 3, 1987.
}

${ }^{5}$ F. George makes this point very well in Sartre, ed. C. Bourgeois, Paris, 1976, II, I, ch. 5. 
writer through political commitment: you can get rid of a neurosis but you are never cured of yourself. ${ }^{6}$ Thus his politics, particularly in the Critique of Dialectical Reason, as has often been shown, approach collective existence on the basis of an individual praxis modelled on the form of intentional consciousness (as lack, non-coincidence, pure movement towards. . .), just as Rousseau's natural man was the measure for the principles of his Social Contract. The legitimization of existence through the experience of contingency and absolute freedom provides both the instruments and the criteria to approach the social order through the experience of its intelligibility. Sartre's political thought belongs then to a tradition for which political legitimacy is ultimately grounded in a moral or an aesthetic characterization of existence, rather than being understood in terms of institutional or juridical solutions. Again, in Rousseau's Contract human nature is remodelled in order to recreate in social existence the unity which was that of the solitary individual, ${ }^{7}$ and on the basis of the natural feelings of compassion or pity ${ }^{8}$ social virtues can lead to the transparency and unity of the hearts of men in the community-which the Revolution will call "fraternity" and attempt to make one of the bases of the new social order. This "politics of virtue" is echoed by Sartre's "politics of freedom," his attempt, as Merleau-Ponty put it, to "give freedom a political line, $"$ " not on the basis of a set of intimate feelings defining natural man of course, but on the basis of Sartre's intuition of his own illegitimacy answered by his philosophy of aesthetic freedom.

But beyond this common moralism, it is the difference between their political projects which is instructive and which simultaneously sets Sartre quite apart from Rousseau's political thought. In his Contract Rousseau tries to translate the ideals of natural existence into conventions and artificial

${ }^{6}$ Les Mots, Gallimard, Paris, 1964, p. 212 (Wonds, Penguin Books, London, 1967, p. 157).

${ }^{7}$ Rousseau, Du contrat social, Pléiade, Tome III, Paris, 1964, Livre Il, ch. 7.

${ }^{8}$ Rousseau, Discours sur l'origine et les fondements de l'inégaliké parmi les hommes, Pléiade, Tome III, Paris, 1964, preface.

9Merleau-Ponty, Les Aventures de la dialectique, Gallimard, Paris, 1955, p. 257 (my translation). 
institutions, and he does this primarily through the Law which, as the expression of the General Will, gives concrete reality to the contract in each society. Natural man is denaturalized, and his natural rights are alienated: they are exchanged for new ones in order to establish a social order which will permit men to live freely with others. ${ }^{10}$ Sartre, on the other hand, attempts to extend the form of the individual project, when, in the Critique, he makes individual praxis the "mould" for common praxis" and the "motive force" of social unification. ${ }^{12}$ The latter is undeniably a development when compared to the conflict of the looks in Being and Nothingness: through the introduction of the unifying Third, each praxis can become the Same as the others by interiorizing, through a common project, the multiplicity of praxes; and this implies that reciprocity, and not individual authenticity, is the standard for collective existence and for the very definition of what is human. But since this standard is directly at work in the Critique's approach to the forms taken by any political order, the modes of common praxis (from fusion to pledge to organization to institution) become moments of a degradation in relation to the cardinal moment of fusion which, alone, embodies that moral standard of reciprocity. This is confirmed, in the Critique, by the way reciprocity formally reproduces the authenticity of Being and Nothingness. Just as freedom had no other end than itself, which excluded any external moral imperative, common praxis cannot rest on any totality, whether historical (History as Progress or Reason) or social (the

${ }^{10}$ Rousseau, Du contrat social, Livre 11, ch. 4.

"Critique de la raison dialectique, Gallimard, Paris, 1960, p. 543. (Critique of Dialectical Reason, hereafter: CDR, NLB, London, 1976, p. 551). In this paper I will use vol. I of the Critique in order to better understand aspects of Sartre's political thought, as has often been done (one of the best analyses remaining, in my view, that of $\mathbf{R}$. Aron: Histoire et dialectique de la violence, Gallimard, Paris, 1973). However this implies to a large extent leaving aside the explicit intentions of the work, to give marxism an epistemological supplement, and therefore running the risk of transforming Sartre's epistemological terms into positive political categories. Even if an internal reading is essential of course (as conducted recently, for example, by J. Catalano, A Commentary on J. P. Sartre's Critique of Dialectical Reason, University of Chicago Press, 1986; and for vol. Il by R. Aronson, Sartre's Second Critique, University of Chicago Press, 1987), I feel nevertheless that this use of the Critique is not only legitimate but indispensable to eatablish the coherence of Sartre's relation to politics.

${ }^{12}$ Critique, p. 361 (CDR, p. 322). 
group as a hyperorganism). Also, just as the For-itself constantly attempted to objectify and recuperate its own spontaneity through reflexion and the constitution of an Ego, the group attempts to maintain itself against its dissolution through a pledge, ${ }^{13}$ that is through the internal violence of fraternity-terror and its subsequent forms. And again, just as the perspective of authenticity was not a rejection of reflexion but rather an attempt to define the path of its purification, the perspective of reciprocity does not reject the pledge-it is the "origin of humanity" says Sartre ${ }^{14}$; one can even say that he makes of a purified pledge the decisive, although implicit, theme underlying the whole Critique. ${ }^{15}$ But this implicit horizon remains irrevocably "out of bounds": it implies breaking the mesh of violence, the original violence of matter, from which stems the counter-violence of group praxis; and only the overcoming of scarcity and need, that is of the very basis of history and of humanity as we know them, can fulfill this requirement. ${ }^{16}$ The problem here is not so much Sartre's so-called historical pessimism, as the fact that the political transposition of his earlier "radical conversion" structures the Critique (and this is true of the whole of Sartre's political thought) in such a way that positive consideration of political legitimacy is constantly both sought and excluded; by political legitimacy I mean an order of institutions embodying the specific constraints of the public sphere of existence. In Sartre's approach no form of collective existence other than the ephemeral moment of fusion can provide an adequate translation of the standard of reciprocity. The Apocalypse of fusion obviously cannot serve as a yardstick or even an ideal reference in the elaboration of a political order, since it is defined (between the "violence of

\footnotetext{
${ }^{13}$ See the role of pledge or vow in L'Etre et le neant, Gailimard, Paris, 1943, concerning the love relationship (p. 434) and the constitution of a character (p. 637) (Being and Nothingmess, Philosophical Library, N. Y., 1956, pp. 367, 552).

${ }^{14}$ Critique, p. 453 (CDR, p. 436).

${ }^{15}$ Later Sartre will state clearly that what he likes about the student movement after 1968 is that it seems to embody the continuity of spontaneous action: "Aucune institution ne s'interpose entre l'expérience et la réflexion sur l'expérience": "Masses, spontanéité, parti," in Situations VIII, Gallimard, Paris, 1972, p. 267.

${ }^{16}$ Critique, p. 201 (CDR, pp. 123-4).
} 
necessity" and the "necessity of violence") as that which escapes institutional petrification. Any legitimate articulation of the individual to the whole of society seems excluded by what amounts to a politics of reciprocity, that is to say an anti-political politics, where the requirements of reciprocity contradict the political nature of the political. As opposed to Rousseau, Sartre does not create a method for the elaboration of legitimate forms of collective existence, but a logic for the subversion of all such forms.

In order to better understand this subversion of the political as such, one must think back to anarchism in a more strictly historical sense. In the XIXth century the critique of the bourgeois political order resulting from the French Revolution (and, according to many, betraying its ideals) is largely a critique of the separation of that order from society, a denunciation of the hypocrisy and formalism of bourgeois democratic institutions. Generally speaking, that critique is conducted either in terms of a reunification of the spheres of civil society and the State through the latter (broadly speaking this is the Hegelian conception, and that of the socialist tradition especially in its concern with strategies of transition and problems of power, which led to the "science" of politics of leninism and stalinism); or in terms of the abolition of the political sphere in the name of a spontaneous accord between men as economic forces. This anarchist tradition, primarily initiated by Proudhon in France, ${ }^{17}$ is partly inspired by Rousseau's idea of the contract as a unity of wills, but at the same time it vigorously opposes it to emphasize another aspect of his thought: direct democracy and the rejection of political representation. In that way anarchism does away with the political dimension of Rousseau's project, claiming that the political institutions of the General Will, namely the Law and the Government, contradict an authentic community of citizens. In the end the anarchist contract limits itself to the self-organization of social forces through a multiplicity of small contracts, one leading to the other and excluding any overall political or juridical fiction uniting them, since this would imply the alienation of particular

\footnotetext{
${ }^{17}$ On this, see P. J. Proudhon, Idée générale de la Révolution au XIX'-siécle, Garnier, Paris, 1851, Quatrième étude: "Du principe de l'Autorité."
} 
citizens' rights to the Whole. ${ }^{18}$ As mentioned above, Sartre takes this path when he extends the model of intentional consciousness to group existence. It leads him to the only "contract" he would consider legitimate: the transparency of the group in fusion. ${ }^{19}$ Indeed his principle of individual praxis, when understood as a criterion for political legitimacy, goes even further than this anarchism since the legitimate modes of collective economic existence in the various anarchist and utopian schemes of the XIXth century, such as associationism, mutualism, federalism, are themselves expressions of pratico-inert alienation, no less than the obvious institutions of the State or the Law. ${ }^{20}$ Thus both Sartre and anarchism define a political project on the basis of a critique of all political institutions as such. And it is this paradoxical pattern of political practice which is characteristic of those movements of direct democracy of the seventies in France with which Sartre will feel at home.

One of the obvious features of this paradoxical project, which relates it so intimately to Sartre's trajectory, will enable it to have a considerable impact in the seventies in Europe: it will manifest itself through a constant reference not primarily to anarchism but to marxism, socialist revolution and the proletariat. Discarding any concern with influences or orthodoxy, I will make a brief

\footnotetext{
${ }^{18}$ The ambiguities of Rousseau's political thought are well-known, and have led to him being interpreted, on the one hand, as the initiator of a tradition of moral regeneration, in which case his opposition to political representation is seen as a fundamental aspect of his thought; or on the other hand, in a Kantian reading, as initiating a tradition for which regeneration remains in doubt, where the spheres of individual morality and public life are kept separate, in which case his opposition to political representation is given a weaker meaning: representation is not scen as a failure to realize man's unity with himself but as corresponding to necessary social divisions for the realization of freedom.
}

${ }^{19}$ Some of the formulations Sartre gives to his opposition to political representation are particularly telling, for example when he says that the problem is not to find a man to represent five thousand others but to find a way for that man to be those five thousand others: On a raison de se révolier (with P. Victor and P. Gavi), La France sauvage, Paris, 1974, p. 305.

${ }^{20}$ One could suggest in that sense that Sartre is maybe closer to Stimer's radical Egoism than he is to Proudhon. 
historical point to try to shed light on this. A decisive aspect of Marx's thought, that is seldom sufficiently stressed but was dominant in his first works and set an important pattern for his and subsequent political thought, is his critique of the separation of politics as a distinct sphere of existence, what Marx calls in the Jewish Question the "double existence" of man and citizen (in Rousseau's terms) or of civil society and the State (in Hegel's terms). Over and against the illusion and the separation inherent in bourgeois democracy, Marx wants to achieve a real or "actual democracy" by realizing man's species being or generic being which is not represented in a separate sphere but is immediately political. ${ }^{21}$ By reason of his labor and his needs, man is the immediate representative of other men, since the species is immanent to the individual, and this generic life must and will be rediscovered in the historical process. Rather than redefine politics against its bourgeois form, Marx claims to absorb a fictitious and separate sphere into a real unity, and this opens a practical perspective that avoids the political problem as such in the name of a coming apolitical unity. These two key factors, generic existence and history, are given a new meaning in Sartre's marxism of course: individual praxis and reciprocal common praxis define the historical totalization as intelligible, rather than production relations; and ultimately totalization can only deliver its promise of true reciprocity through a most problematic overcoming of scarcity. As a result, the political institutions dismissed by Marx as unreal are thoroughly discussed by Sartre: the existence of a stalinist party and State caused him after all to rethink Marxian epistemology. He approaches these institutions as a degradation of individual praxis, therefore as forms of violence, which implies that the historical process has become locked in the circle of institutional violence. If these differences with Marx shed light on Sartre's social thought, it is because he develops them on a basis which is in fact very close to the position of the early Marx (his critique of politics), while resting on Sartre's own philosophical foundations (the standard of transparency, the horizon of fusion). By socializing the problematic of individual freedom Sartre seems to provide a specific version of what can be described as the anarchism of Marx's early critique of separation in bourgeois

\footnotetext{
${ }^{21}$ Marx, Economic and Philosophic Manuscripts of 1844, First Manuscript ("Estranged Labour") and Third Manuscript ("Private Property and Communism"), on man's "species being"; and on civil society as "actual political society": Contribution to the Critique of Hegel's Philosophy of Law (commentary on paragraph 308). See Marx-Engels, Collected Works, vol. 3, New York, 1975.
} 
politics. ${ }^{22}$ The texts before the Critique, ${ }^{23}$ where Sartre explains some of his philosophical reasons for adhering to marxism, are most telling here: for example when he states that the proletariat unhindered by any institutional or ideological inertia embodies pure possibility and thus the authenticity of praxis itself. The radical alienation of the proletariat allows it to express the pure freedom which defines humanity 24 -in the same way, one could say, as Rousseau's "peuple" is spontaneously good, expressing by the simplicity of its condition something of man's good nature before the corrupting effect of socialization. When Sartre constructs his own social philosophy later on in the Critique, his approach is somewhat more subtle, but the fundamental reasons behind his attraction to marxism remain unchanged, as his analyses of Engels' economism make clear: according to Sartre they reduce history to a process of production and expel the struggle of praxis from it. ${ }^{25}$

In this way, like many others in the sixties and seventies, Sartre is able to criticize stalinist marxism in the name of Marx, without questioning Marx's original relation to politics, namely that since man is directly sociable, all political institutions must be demystified because they separate man from

${ }^{22}$ An important French commentator of Marx writes, for example, of the young Marx's "anarchisme anti-politique réalisable par un mouvement politique": M. Rubel, "Marx, théricien de l'anarchisme," in Marx critique du marxisme, Payol, Paris, 1974, p. 57. Of courae, Marx will later launch ferocious altacks on such thinkers as Proudhon (in The Holy Family) and Stirner (in The German (deology); but his basic thesis on politics is not the object of these polemics.

${ }^{23}$ Primarily "Les communistes et la paix," in Situations VI, Gallimard, Paris, 1964, brilliantly analyzed and criticized by Merleau-Ponty in Les Aventures de la dialectique.

24"Le prolétariat n'est qu'en acte, il est acte," writes Sartre ("Les communistes et la paix," p. 207). From this follows the role altributed to the party of the proletariat (at a time when Sartre strongly feels the need to work with the French Communists) as its unifying principle, without which the proletariat is nothing and returns to dust. The party can then be defined as "I'incarnation pure et simple de la praxis" ("Les communistes et la paix," p. 247). See also "Matérialisme et Revolution," in Situations III, Gallimard, Paris, 1948, on how social revolution gives expression to the essential illegitimacy of the oppressed and thus to human freedom.

${ }^{25}$ Critique, pp. $669-70$ (CDR pp. 710-12). 
himself. For Sartre, however, not only are these institutions a mystification, ${ }^{26}$ they also embody a hidden violence which requires counter-violence so that man can resist what separates him from himself and from others. Political practice can then be reduced to a movement of spontaneous and violent reaction or resistance to the violence of institutionalization-whether it be that of bureaucratic stalinism, fascism or liberal democracy-; and as a result actual political action receives from its non-political end a rationale of revolt against all power. When this anarchism, which constantly refers itself to marxism and takes the form of defiance and resistance towards all institutional politics, comes to life historically in France in 1968, Sartre finds a concrete confirmation of his efforts and something of a political home for his initial philosophy of freedom. Everything is indeed possible when the only principle is a non-principle: spontaneity, and when the struggle is directed not so much against the State or the ruling-class but against any and all forms of social inertia. Decapitated of any political expression, Rousseau's political moralism becomes in Sartre the feeling of immediate reciprocity which can emerge from direct relations between individuals: either in exceptional and instantaneous mass fusions (where it is only accessible through historical imagery), or more often in the experience of friendship, small-scale cooperation, intimate fraternity, which Sartre so appreciates in the leftist groups he works with in the seventies.

What is so striking in Sartre's political itinerary is that he is constantly, and often explicitly, trying to come to grips with some of these very difficulties. When in the postwar years he battles with his own moralism and with his often discussed "problem of mediations," 27 he revives Hegel's critique of Rousseau's abstract politics, which had produced, through the practice of the Jacobins, the Terror of the French Revolution as a result of trying to realize the

\footnotetext{
${ }^{26}$ This is the case for the formal rights of bourgeois democracies, criticized by Marx in On the Jewish Question, which became a powerful theme for political activists fighting liberal democracy in the seventies.

${ }^{27}$ Along with L'Existentialisme est un humanisme, Qu'est-ce que la littérature?, Les Chemins de la liberié and Les Mains sales, the most important work for this is Le Diable et le Bon Dieu (1951). Sartre is constantly attacking a purely formalistic or aesthetic conception of freedom, in the name of the concrete realization of moral values. The Cahiers pour une morale, published posthumously (Gallimard, Paris, 1983), illustrate Sartre's considerable theoretical efforts in this direction in 1947-49.
} 
General Will immediately instead of embodying freedom in the adequate social institutions and thereby consenting to a necessary alienation of freedom. ${ }^{28}$ Coming after Merleau-Ponty's analyses, the Critique is Sartre's effort to confront on the theoretical plane the very problem of institutions and of social passivity, left unthought by marxism. But if the bad conscience of the moralist has disappeared, Sartre does not change his basic course; such a change would imply thinking through the relationship between, on the one hand, ontological freedom as the transcendence of the For-itself or, in the Critique, as counter-violence, and, on the other hand, a specifically political freedom defined through the constraints required for its realization. ${ }^{29}$ The pattern of absolute freedom "eating away" freedom itself as defined in Being and Nothingness, ${ }^{30}$ or of praxis "eating away" praxis in the Critique as expressed through the telling dualities of "pratico-inert" and "fraternity-terror," does not deny, in any way, the resistance of things and the adversity of other men; but it forces one to define politics simply as the free act of radically overcoming adversity in the name of reciprocity.

This pattern provides Sartre with a formidable weapon for the critique of institutional politics, but it limits his own positive interventions to a series of antinomies which, without the common reference of individuals to some Law, exclude the possibility of deliberation, dialogue and therefore compromise. This can be illustrated both well before and well after the Critique on the question of spontaneity and organization. For example, during the discussion of a "parti-milieu" and "parti-mouvement" at the time of the R. D. R. in 1948,

\footnotetext{
${ }^{28}$ Hegel, "Absolute Freedom and Terror," in The Phenomenology of Mind, Humanities Press, New York, 1971.

29" "Le mouvement de libération implique une fin, c'est-d-dire l'abolition de toutes les entraves," writes Sartre with his maoist companions in 1974: On a raison de se révolter, p. 346. H. Arendt's general characterization of the problem of modern revolutions is particularly pertinent for Sartre: she deplores their incapacity to distinguish between liberation (from various forms of oppression and misery) and political freedom (as the organization of a specific public ephere of existence): On Revolution, Penguin Books, New York, 1963.
}

${ }^{30}$ L'Etre et le néant, p. 560 (Being and Nothingness, p. 480). 
$31_{\text {and again concerning the maoist notion of "creuset" (melting-pot) }}{ }^{32}$ in the seventies, Sartre endlessly confronts the contradictory requirements of "liberterévolte" and "liberté-pouvoir, ${ }^{33}$ or simply recognizes that he has no solution to offer concerning the problem of stable structures both required by political action and threatening it by inertia. ${ }^{34}$ In the seventies, his anti-institutionalism reaches its peak when he discusses such issues as the political status of the revolutionary intellectual, of the teacher or of the psychoanalyst, ${ }^{35}$ where a logic of exclusion moralizes each question in a spirit which is best expressed, in earlier texts on third-world liberation, by the demand that man "recreate himself" through violent revolt, ${ }^{36}$ or better still by this even earlier description of the poetry of negritude:

Thus negritude is dialectic, it is not only nor primarily the unfolding of atavistic instincts; it represents the surpassing of a fixed situation by a free conscience. Myth dolorous and full of hope, Negritude, born of Evil and pregnant of a future Good, and living as a woman who is born to die and who senses her own death even in the richest moments of her life, it is an uneasy repose, an explosive stability, a pride which renounces itself, an absolute which knows itself to be transitory. Because in the

${ }^{31}$ Entretiens sur la politique (with D. Rousset and G. Rosenthal), Gallimard, Paris, 1948.

${ }^{32}$ On a raison de se révolter, p. 114-5.

${ }^{33}$ On a raison de se révolier, p. 350-2.

34 "Masses, spontanéité, parti," in Situations VIII, p. 283.

${ }^{35}$ See respectively "L'ami du peuple" and "La jeunesse piégée" in Situations VIII; and "L'homme au magnétophone," in Situations IX, Gallimard, Paris, 1972.

${ }^{36}$ Preface to Fanon's Les Damnés de la terre, in Situations V, Gallimand, Paris, 1964: "Quand sa rage éclate," writes Sartre of the colonized, "il retrouve sa transparence perdue (. . .) le voici légitimé par un droit qui va naître, qui naît chaque jour au feu" (pp. 183-84). 
same time that it is prophet of its birth and of its agony, it remains the existential attitude chosen by free men and lived absolutely, to the dregs. 37

Some of Sartre's expressions here are reminiscent of Anny's "perfect moments" in Nausea, and describe impeccably the fleeting moment of the group in fusion; they are perhaps his best statement of the nature of political legitimacy in his view, of its underlying aesthetic motive, of the artist's posture as its basic model. This model implies no flight from the political scene however, no avoidance of social commitment or responsibility: Sartre "shoulders the burden" of the political constraints of his epoch, but according to a non-political mode, with such criteria as freedom of the imagination as opposed to inertia, and the unanimity of fusion as opposed to conflict, enabling him to make dramatically obvious the moral and ontological stakes, but simultaneously making him avoid the articulation of the opposing poles he brings to the fore-that articulation being precisely, one could argue, the object of political theory.

Dismissing the General Will and disqualifying as "absurd" the dictatorship of the proletariat, ${ }^{38}$ the Critique renders explicit what Sartre's practical interventions will illustrate in the seventies: the questioning of any general political project: "If it were really necessary to find a foundation for sovereignty, we would be searching for a long time: for there is no such thing

37" Orphée noir" (1948) in Situations III, pp. 283-4 (quoted here from the transiation by S. W. Allen, Black Orpheus, ed. Présence africaine, 1963, p. 63, my underlining). What intereats Sartre in the forms of anti-colonial struggles is precisely that in these cases traditional institutional politics are powerless, and the violence required directly embodies his basic conception of freedom. For Sartre these struggles are not seen as a particular case of political action; rather they provide a model for a general political posture which expresses his moral requirements. With this model, Sartre analyzes the individual revolt of the outcast, and he allempts to underetand the revolutionary potential of the proletariat in terms of its fundamental illegitimacy. One of the cleareat theoretical formulations of this pattern of revolt, while concerning Jean Genet, occura in the work on Flaubert: L'Idiou de la famille, Gallimard, Paris, 1971-2, vol. I, pp. 831-4.

${ }^{38}$ Critique, p. 630 (CDR, p. 662). 
(. . .) Man is sovereign. ${ }^{n 39}$ History remains the framework of course, but as an unfinished totalization, as the scene of an infinity of mediations between men and things, praxis and inertia, not as Progress, Reason or even Revolution. Sartre's position remains that of the "universal intellectual," aiming at a global alternative project in terms of an historical finality and structured by the experience of freedom frustrated by power and finally overcoming it. But everything indicates that the Critique's rethinking of marxism is, despite itself, carefully putting in place all that is required to ruin such a project, as if Sartre was pointing toward a radical questioning of the traditional, finalist and sovereignist, vision of political legitimacy, since there remains no central power to be seized by the revolutionaries and no distinctions and degrees in political institutions to be worked on by the reformists. What is left (for the "beautiful souls"?) is a politics of punctual, local resistance with no other end than itself, and aesthetic anarchism; and this is by no means an abstract construction since it corresponds to the concrete militancy of the seventies in which Sartre revelled, characterized at once by a refusal to go beyond freedom as sheer independence and revolt, and by the demand that these values of individual independence be given immediate reality-which is tantamount to squaring the circle. ${ }^{40}$ Hence I think it is not possible to say more concerning the meaning of this political thought today than simply to acknowledge that Sartre's failure in the Critique opened the door for the current wave of post-marxism. ${ }^{41}$

What is at stake may be discernible by relating Sartre's politics to that of another contemporary thinker, Foucault, apparently Sartre's philosophical opposite, but himself very much at home in the movements of the seventies in France and to whose work those same terms of anarchism, local resistance and political aestheticism have often and quite correctly been applied. Like Sartre conducting simultaneously his analyses of the pratico-inert and group violence and his practice of punctual resistance to all power, Foucault minutely decodes the modern system of normalization and social control while participating in

${ }^{39}$ Critique, p. 588 (CDR, p. 610).

${ }^{40}$ Asked what the student of 1968 wanted, Sartre answers: "Nothing," that is "everything: freedom": "Autoportrait a soixante-dix ans," in Situations $X$, p. 184.

${ }^{41}$ As Aronson suggests at the end of his Sartre's Second Critique, p. 237. 
localized and limited initiatives of contestation. Whatever their differing intentions, they both seem to be encouraging all initiatives which undermine power relations and to be providing tool kits whereby social institutions can be demystified; but nothing more. "I think that to imagine another system is to extend our participation in the present system, ${ }^{42}$ says Foucault; and Sartre, as well as the activists of the seventies, would concur. Any general political project means new controls and new disciplines, for Foucault; it means the cycle of petrification and violence, for Sartre. So while Sartre's effort is to construct a justification for something more than immediate resistance to power, whereas Foucault's effort is to deconstruct any such justification; and while Sartre constantly moralizes politics whereas Foucault describes its amoral functioning, they nevertheless find themselves with similar political stances.

What makes them so different and yet so similar can be found in the philosophical positions underlying their politics. Foucault's politics follows from his Nietzschean diagnosis of the modern world as nihilism, and if he is at ease in the post-' 68 period it is because the philosophical significance of that social movement is by no means a triumph of humanism, as is often suggested, but a questioning of any moral or political order in the name of individual independence, of relativism, of what was often referred to at that time in France as "le droit a la différence." Foucault's deconstruction of the will to truth and his guerrilla style of political writings (on medical, carceral, sexual power relations) both correspond to and enhance such an ethic of resistance. On that basis Foucault has no trouble reading the difficulties of Sartre's unfinished project of historical intelligibility, and his continual effort to establish some sort of universality allowing for coherent moral and political action, in terms of the inevitable impasse of modern anthropologies caught in the circle and the doubles of the "analytic of finitude. ${ }^{\text {43 }}$ Whether it is by trying to conciliate phenomenology and marxism or by trying to salvage some transcendent

\footnotetext{
${ }^{42}$ Foucault, Interview in Actuel (1971) reproduced in Language, Counter-memory, Practice, D. Bouchard (ed.), Comell University Press, 1977, p. 230.

${ }^{43}$ Foucault, Les Mots et les choses, Gallimard, Paris, 1966, ch. DX.
} 
reference through historical totalization, ${ }^{44}$ all this only shows that the Nietzschean message of the Death of God has not been understood in its full significance as the Death of Man. But what is too often forgotten when discussing Sartre's politics, is that his own original philosophy-his critique of any substantial Ego as a unified subject, his critique of morality as flight from contingency, his critique of humanism as "spirit of seriousness" - is itself deeply akin to Nietzschean nihilism. Even if, from Being and Nothingness on, these critiques are conducted in the name of freedom, it is a freedom of spontaneity, of creativity and imagination that structures all aspects of Sartre's thought. The important difference with Foucault then is that rather than developing the implications of this philosophy and rejecting any moral standard external to the movement of freedom itself, Sartre attempts to redirect his original position towards humanism, in an effort to construct after the war a morality and a politics on a philosophical basis which constantly undermines what it is supposed to underpin. This difficult philosophical posture is, in part at least, the breeding-ground for the anti-political anarchism I have tried to describe above.

Just as Sartre's politics can be understood by reference to the French Revolution's myth of regeneration and quest for a new social order, inasmuch as this corresponds to his own quest for legitimacy and for a personal order, Foucault's politics also proceed from that crisis symbolized by the beheading of the King. But for him this event, although it does capture the condition of modern man having lost his marks, is not the symbol of a new existential or philosophical quest for meaning. Such a quest, according to Foucault, would only lock itself in the interminable experience of finitude. No longer the symbol of a search for a new political legitimacy, it is rather the sign that a tradition of politics conceived in terms of sovereignty and centralized power ${ }^{45}$ has come to an end. It calls for quite a different relation to power, a relation practiced to some extent by the "irresponsible" anarchists of the seventies who, far from trying to seize power, were inventing ways of challenging, mocking and avoiding it. Political theory and practice which remain in the traditional framework, attempting to extend or to reverse the contractual idea of legitimacy

\footnotetext{
${ }^{44}$ Foucault, Les Mots et les choses, p. 332, and L'Archéologie du savoir, Gallimard, Paris, 1969, p. 24.

${ }^{45}$ Foucault, Surveiller et Punir, Gallimard, Paris, 1975, ch. II.
} 
by proposing or struggling for alternative forms of power without breaking out of the model of the former ones, are, in Foucault's view, hopelessly anachronistic and can only produce repeated failures. What is required is not so much a new political theory but an attitudinal leap which accepts the impossibility of any general political project. In this view, Sartre's entire personal/political itinerary expresses this anachronistic stance (particularly his relationship to marxism) since he endlessly both seeks and ruins the possibility of such a project; whereas Foucault strives, not to overcome the problem, but to reveal it by an original approach to power (as dispersed, multi-facetted) and to resistance (as immanent to power itself.) ${ }^{46}$ However, rather than trying to read Sartre through Foucault's categories, or the reverse, I would suggest that just as they found themselves side by side in the streets on various issues in the early seventies, Sartre's humanist anarchism and Foucault's nihilist anarchism, albeit with radically differing styles and explicit aspirations, nevertheless echo each other as two ways of answering an original and common philosophical experience of powerlessness-and this, I think, by both pointing ultimately to the aesthetic sphere of existence.

The notion of "transgression" by which G. Bataille characterizes eroticism ${ }^{47}$ provides a way of understanding Foucault's theoretical (or should one say: antitheoretical) stance, as an overstepping of the limits given by a rule but imperatively requiring that rule in order to perpetuate itself as a transgression. This also seems to be what is at stake in an anarchism which rejects any alternative political system, has no other end than its own movement of revolt and feeds off the power relations it is forever challenging. Doesn't this also suggest a way to understand Sartre's social ethic based on the surge of freedom with all its political consequences, even if these are constantly claiming to express the very opposite of an aesthetic of transgression, namely an ethic of

\footnotetext{
${ }^{46}$ Foucault, La Volonié de savoir, Gallimard, Paris, 1976, pp. 121-135.

${ }^{47}$ Bataille, L'Erotisme, Editions de Minuil, Paris, 1957.
} 
effective action and historical transformation? Sartre's politics might best be described and read, not as failure, but as a meticulous and brilliant exposition over forty years of what, in Foucault's thought, is the implicit starting point: "qui perd gagne" (loser takes all). ${ }^{48}$

${ }^{48}$ Les Mots, p. 213 (Wonds, p. 158). 